\title{
https://doi.org/10.46813/2021-136-022 RADIATION INDUCED SOFTENING OF CRYSTALS
}

\author{
V.I. Dubinko, V.N. Borysenko, V.A. Kushnir, I.V. Khodak, V.V. Mytrochenko, V.O. Gamov \\ National Science Center “Kharkov Institute of Physics and Technology”, Kharkiv, Ukraine
}

Under irradiation of crystals, atomic vibrations of the lattice that are large enough in amplitude so that the linear approximation and therefore the conventional phonon description of the lattice is not enough. At the same time, these vibrations are localized and can travel long distances in a crystal lattice $[1,2]$. In metals and other crystals, they are called discrete breathers (DBs), which are the secondary products of irradiation damage, the primary one being the creations of defects that involve atom displacements to produce point and extended defects, which results in radiation induced hardening $(\mathrm{RIH})$. A part of the remaining energy transforms in DBs before decaying into phonons. Thus, while a material is being irradiated in operational conditions, as in a reactor, a considerable amount of DBs with energies of the order of one $\mathrm{eV}$ is produced, which helps dislocations to unpin from pinning centers, producing Radiation Induced Softening (RIS), which opposes RIH [3, 4]. This effect is investigated under (in-situ) impulse and steady-state electron irradiation.

PACS: 61.80.x, 63.20.Pw, 87.15.Aa

\section{INTRODUCTION}

One of the main factors limiting the service lifespan of the nuclear reactors is the radiation-induced embrittlement caused by the radiation-induced hardening of $\mathrm{Fe}$ based steels used as structural materials for pressure vessels etc. Defects formed by irradiation in the bulk act as additional pinning centers, resulting in the well-known effect of radiation-induced hardening (RIH). On the other hand, there is experimental evidence of radiation-induced softening (RIS) under electron, gamma or neutron irradiation at low and medium temperatures. The RIS has been discovered in the early 1960s [5] and investigated extensively thereafter (see e.g. [6]). Single crystals of $\mathrm{Zn}, \mathrm{Sn}$, In and $\mathrm{Pb}$ have been irradiated at liquid nitrogen temperature $(78 \mathrm{~K})$ with electron flux density ranging from $10^{17}$ to $10^{18} \mathrm{~m}^{-2} \mathrm{~s}^{-1}$ and energies below and above the threshold displacement energies, the latter being $0.7 \mathrm{MeV}(\mathrm{Zn}), 0.8 \mathrm{MeV}$ (Sn, In) and $1.2 \mathrm{MeV}(\mathrm{Pb})$. At such low temperatures plastic strain occurs via dislocation glide, the rate of which is limited by thermally activated unpinning of dislocations from local obstacles. Subsequently, new experimental evidence was obtained on the radiationinduced increase of plasticity of polycrystalline $\mathrm{Cu}$ (99.5\%), $\mathrm{Al}(99.5 \%)$ and $\mathrm{Al}-3 \mathrm{Mg}$ under in situ electron irradiation at the room temperature [3, 4]. The electron energy of $0.5 \mathrm{MeV}$ used in these experiments was higher than the threshold displacement energy in $\mathrm{Al}(0.15$ $\mathrm{MeV}$ ) and about that for $\mathrm{Cu}$. In all cases, irradiation resulted in the decrease of yield stress and increase of the elongation to fracture, i.e. a metal under irradiation instantly became less hard and more ductile as compared to the state prior and after irradiation. These results demonstrated that mechanical properties of materials under reactor conditions could be different from those tested 'out of pile' in the surveillance program.

The present experiments were designed so that to allow comparison between over-threshold irradiation of $\mathrm{Al}$ and polycrystalline $\mathrm{Fe}$ (and commercial steel 20), which is a base metal of the reactor structural materials in order to make the results more closely related to the real in-reactor environment. For this purpose the beam energy for the Fe irradiation was increased from 0.5 to $0.8 \mathrm{MeV}$, which is sufficient to produce displacement damage at a rate of $10^{-9} \mathrm{dpa} / \mathrm{s}$ (where dpa denotes 'displacements per atom') which is comparable to the dose rates in nuclear reactor environment.

The main result obtained here is that the yield stress of Fe is decreased by irradiation, as well as the ultimate resistance to fracture, the latter being in a marked contrast to $\mathrm{Al}$ and $\mathrm{Cu}$ cases, which points out at the radiation-induced localization of plastic strain in Fe. So the Fe-based metal under irradiation became less hard and more brittle at the same time. These results mean that dynamics of dislocations has been changed due to their interaction with radiation-induced excitations of the lattice, the nature of which needs to be determined. The underlying mechanisms of RIS are still a subject of debate [7]. One of the possible mechanisms is based on special kind of lattice vibrations, namely, discrete breathers (DBs), also known as intrinsic localized modes, can be generated either by thermal fluctuations or by external triggering such as irradiation. The amplitude of atomic oscillations in the DBs greatly exceeds that of harmonic oscillations (phonons). Due to the crystal anharmonicity, the frequency of atomic oscillations increases or decreases with raising the amplitude so that the DB frequency lies outside the phonon frequency band, which explains the weak coupling of DBs with phonons and, consequently, their stability against decay even at elevated temperatures. DBs have been successfully observed experimentally in various physical systems [8] and materials ranging from metals to diatomic insulators [9]. This field of research is comparatively new, lying at the conjunction of nonlinear physics with material science. The main hypothesis of the present paper is that DBs present a viable catalyzing mechanism for the dislocation unpinning from obstacles under irradiation that triggers DB generation.

The paper is organized as follows. In the next section, experimental setup is described. In section 3, results of discrete electron irradiation of bcc Fe $(99.5 \%)$ are presented in comparison with analogous results for fcc $\mathrm{Al}$ reported in refs. [3, 4]. In section 4, results of continuous electron irradiation of bcc $\mathrm{Fe}(99.5 \%)$ are presented in comparison with analogous results for steel 20. 


\section{EXPERIMENTAL SETUP}

The present technical approach combines electron irradiation (compact electron linear accelerator, $\mathrm{E}<1 \mathrm{MeV}$ ) with in-situ mechanical testing at the installation, which measures a yield stress drops during irradiation pulses and the stress-strain deformation curve under continuous irradiation. Experimental procedure and installation is described in details in ref. [4]. Electron beam of the energy ranging from 0.5 to $0.8 \mathrm{MeV}$ and the beam density ranging from 2.4 to $3.6 \times 10^{13} \mathrm{~cm}^{-2} \mathrm{~s}^{-1}$ was directed at a metal specimen subjected to tensile load. The time diagram of the electron beam pulses (the fine pulse structure) is shown in Fig. 1. Micro-pulses of duration, $\tau_{\mathrm{m}}=4 \times 10^{-11} \mathrm{~s}$, were shot periodically with an interval of $3 \times 10^{-10} \mathrm{~s}$ during the bunch time, $\tau_{\text {bunch }}=(2 \ldots 4) \times 10^{-6} \mathrm{~s}$. The bunch frequency, $1 / T_{0}$, was $25 \mathrm{~Hz}$. An overall irradiation time ranged from 10 to $3000 \mathrm{~s}$ in different irradiation regimes.

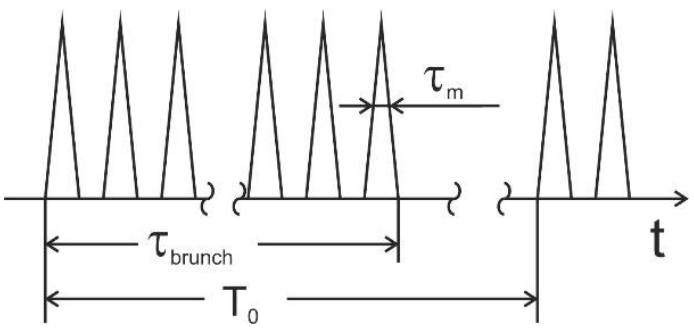

Fig. 1. Time dependence of the electron beam pulses [4]

Specimens had a form of a parallelepiped with broader ends for fixing and the following dimensions of the irradiated part: $0.52( \pm 0.01) \times 4 \times 30 \mathrm{~mm}^{3}$. They were cut of technically pure iron $\left(0.048 \%{ }^{\circ} \mathrm{C}\right)$ annealed in vacuum in two regimes: (1) $\mathrm{T}=900^{\circ} \mathrm{C}$ for 1 hour resulting to a mean grain size of 7 microns; (2) $\mathrm{T}=1150^{\circ} \mathrm{C}$ for 2.5 hours resulting to a mean grain size of $150 \mathrm{mi}-$ crons. At the experimental temperature (slightly above RT), Fe matrix has a bcc structure with impurities precipitated in the form of various obstacles for dislocation glide, which increases the initial yield stress of material (prior to irradiation) to $\sim 200 \mathrm{MPa}$ as compared to $\sim 50 \ldots 100 \mathrm{MPa}$ for technologically pure Fe. The microstructure of the 'steel 20' is much more complex, but principally, it consists of ferritic bcc iron grains (with some Carbon in solution) and a certain fraction of perlite grains, which doubles its strength as compared to the strength of technically pure iron.

The specimens were subjected to uniaxial tensile load in the deformation installation, which was registered in the coordinates - load, $P$, vs. time, $t$, with delay ranging from 1 to $0.3 \mathrm{~s}$ and sensitivity of $0.1 \%$. The load is related to the external stress, $\sigma$, as $\sigma=P(1+\varepsilon) / S$, where $S$ is the specimen cross-section and $\varepsilon$ is the deformation calculated by $\varepsilon=v_{d} \cdot t / l$, where $v_{d}$ is the velocity of the deformation rod, $l$ is the specimen length. The load measurement accuracy was about $(0.1 \ldots 1) \mathrm{N}$. The velocity of the deformation $\operatorname{rod}$ was $0.5 \mu \mathrm{m} \cdot \mathrm{s}^{-1}$, which corresponded to the deformation rate of $\varepsilon \cong 2 \times 10^{-4} \mathrm{~s}^{-1}$, i.e. typically used in the standard tensile tests. The surface temperature of the specimens during testing was measured independently with infrared pyrometer and thermocouples attached to the specimen outside the irradiated area.

Effect of the irradiation on plastic deformation of $\mathrm{Fe}$ and $\mathrm{Al}$ was studied at room temperature applying the discrete and continuous regimes of irradiation. In the first case, specimens were irradiated under external load within the short time intervals $t_{i r r}$ followed by the intervals without irradiation. In the second case, the specimens were irradiated under external load continuously up to the fracture point.

\section{DISCRETE IRRADIATION OF Al AND Fe AT ROOM TEMPERATURE}

In the following tests, the specimens were exposed to discrete irradiation pulses with $t_{i r r} \sim 60 \mathrm{~s}$, during which the yield stress drops sharply by the value, $\delta \sigma_{\varphi}$, and then it increases at a lower rate than that without irradiation, as can be seen in Fig. 2.
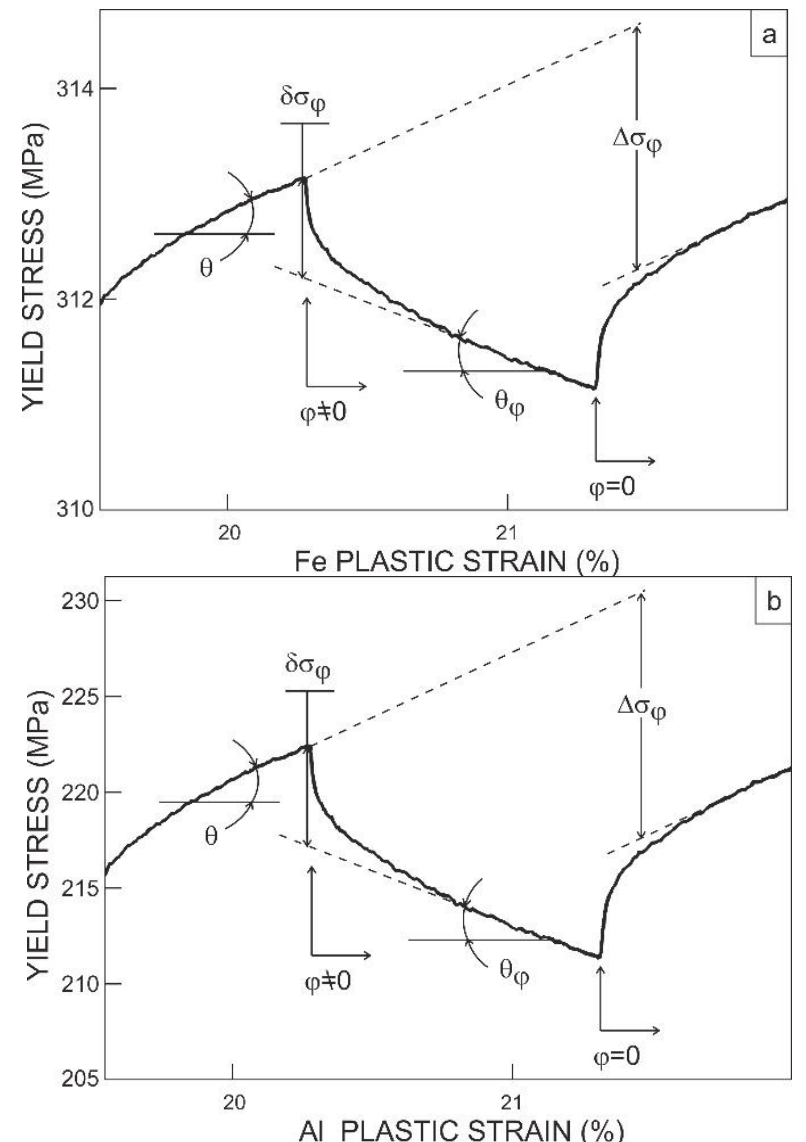

Fig. 2. Yield stress drops during deformation (a) of Fe specimens $\left(T_{a n n}=1150^{\circ} \mathrm{C}\right)$ under electron beam with $E=0.8 \mathrm{MeV}, \varphi=3.6 \times 10^{13} \mathrm{~cm}^{-2} \mathrm{~s}^{-1}$ and $(b)$ Al specimens under electron beam with $E=0.5 \mathrm{MeV}, \varphi=5 \times 10^{13} \mathrm{~cm}^{-2} \mathrm{~s}^{-1}$ [4]

Let us define a deformation strengthening rate as $\theta=$ $\mathrm{d} \sigma / \mathrm{d} \varepsilon$. When the electron beam is switched on $(\varphi \neq 0)$, the yield stress drops sharply by the value, $\delta \sigma_{\varphi}$, and subsequently a prolonged deformation stage occurs, at which the deformation strengthening rate $\theta_{\varphi}$, is always lower than that without irradiation $\theta_{0}$, and it can be even negative for some time. When the electron beam is switched off $(\varphi=0)$, the yield stress jumps up sharply by the value, $\delta \sigma_{\varphi}$, (equal to the initial stress drop) and subsequently grows with time at a rate $\theta_{0}$. As a result, 
the net external stress decreases by the value $\Delta \sigma_{\varphi}$, which indicates that the metal microstructure changes during irradiation, the material becomes more soft under irradiation pulse as compared to the unirradiated state, and the effect persist for some time after the pulse.

The initial stress drop/jump at the moment of the beam switching on/off, $\delta \sigma_{\varphi}$, is shown in Fig. 3 for Fe specimens annealed at $\mathrm{T}_{\mathrm{ann}}=900^{\circ} \mathrm{C}$, which are harder initially than those annealed at $1150^{\circ} \mathrm{C}$. It can be seen that $\delta \sigma_{\varphi}$ increases linearly with increasing deformation and the beam density.
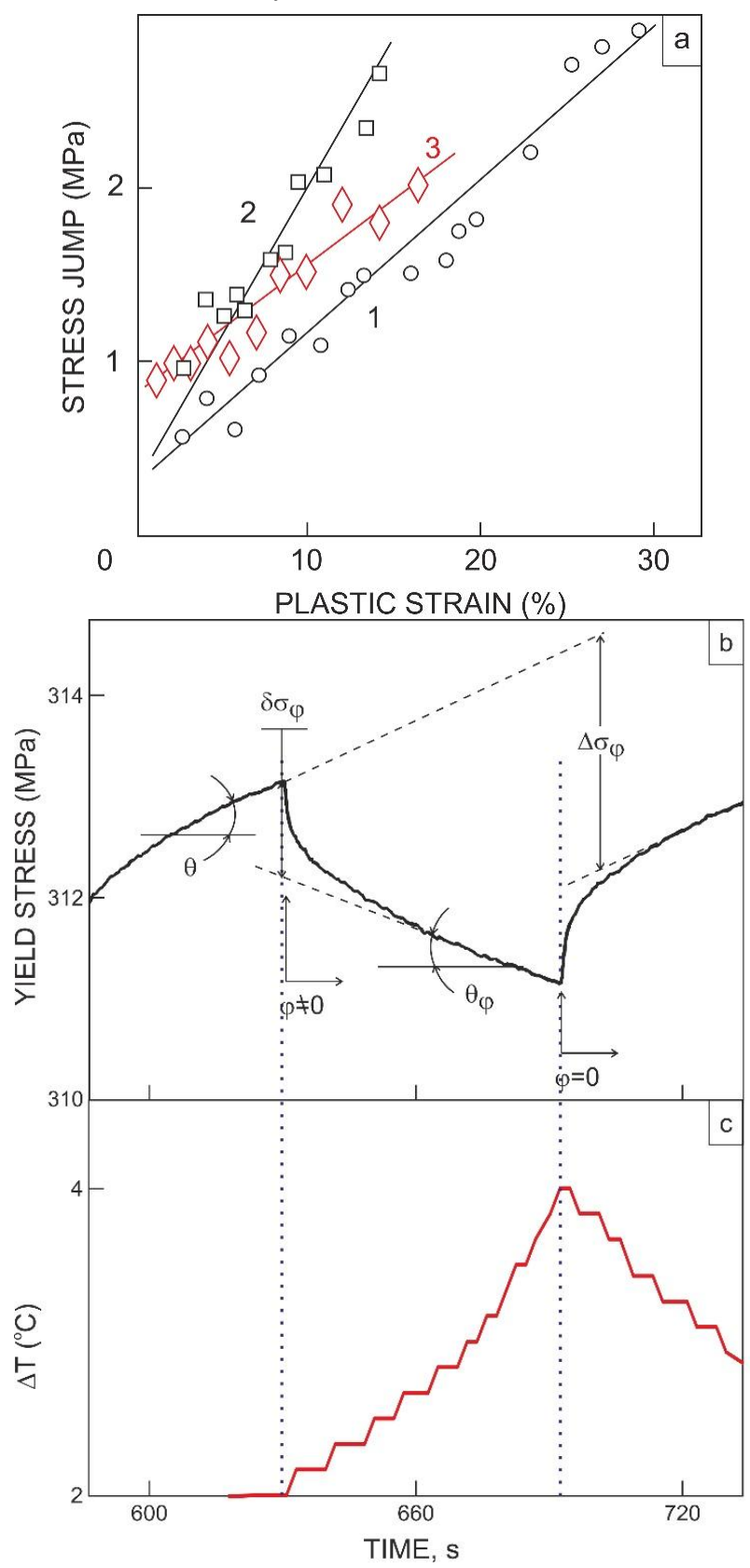

Fig. 3. (a) The initial stress drop/jump at the moment of the beam switching on/off as a function of deformation for Fe specimens $\left(T_{\text {ann }}=900^{\circ} \mathrm{C}\right)$ under electron beam with $E=0.8 \mathrm{MeV}, \varphi=2.4 \times 10^{13} \mathrm{~cm}^{-2} \mathrm{~s}^{-1}$ (line 1);

$3.6 \times 10^{13} \mathrm{~cm}^{-2} \mathrm{~s}^{-1}$ (line 2); Fe specimens annealed at $1150^{\circ} \mathrm{C}$ at $\varphi=3.6 \times 10^{13} \mathrm{~cm}^{-2} \mathrm{~s}^{-1}$ (line 3, color online). Yield stress evolution of Fe specimens $\left(T_{a n n}=1150^{\circ} \mathrm{C}\right)$ during one irradiation cycle is shown in (b) while the corresponding time evolution of specimen temperature is shown in (c)
The value $\delta \sigma_{\varphi}$ characterizes an instant (and reversible) response of the metal to irradiation, which can not be explained by the radiation or strain induced transformation of microstructure that takes much longer times than the times of the stress drops/jumps by $\delta \sigma_{\varphi}$. We may conclude here that during irradiation pulses material becomes softer by two mechanisms. One is reversible $\left(\delta \sigma_{\varphi}>0\right)$ and the other one is irreversible $\left(\theta_{\varphi}<\theta_{0}\right)$, which results in material softening both during and shortly after the irradiation pulse.

\section{CONTINUOUS IRRADIATION REGIME}

During continuous irradiation under increasing strain, the specimen temperature increases gradually as shown in Fig. 4. The deformation curves measured without and under irradiation show that irradiation results in a decrease of the yield stress as well as of the ultimate elongation before fracture of all specimens under investigation. It means that the plasticity limit (strain to fracture) is decreased under irradiation by $\sim 20 \%$, in a remarkable contrast to $\mathrm{Al}$ and $\mathrm{Cu}$ samples for which it was increased by $\sim 25 \ldots 30 \%$ [3, 4]. The result demonstrated in Fig. 4,a was reproduced in four specimens, every time showing significant reduction of the strain to fracture. Clearly, the capacity of the material to sustain plastic deformation is strongly affected by the irradiation.
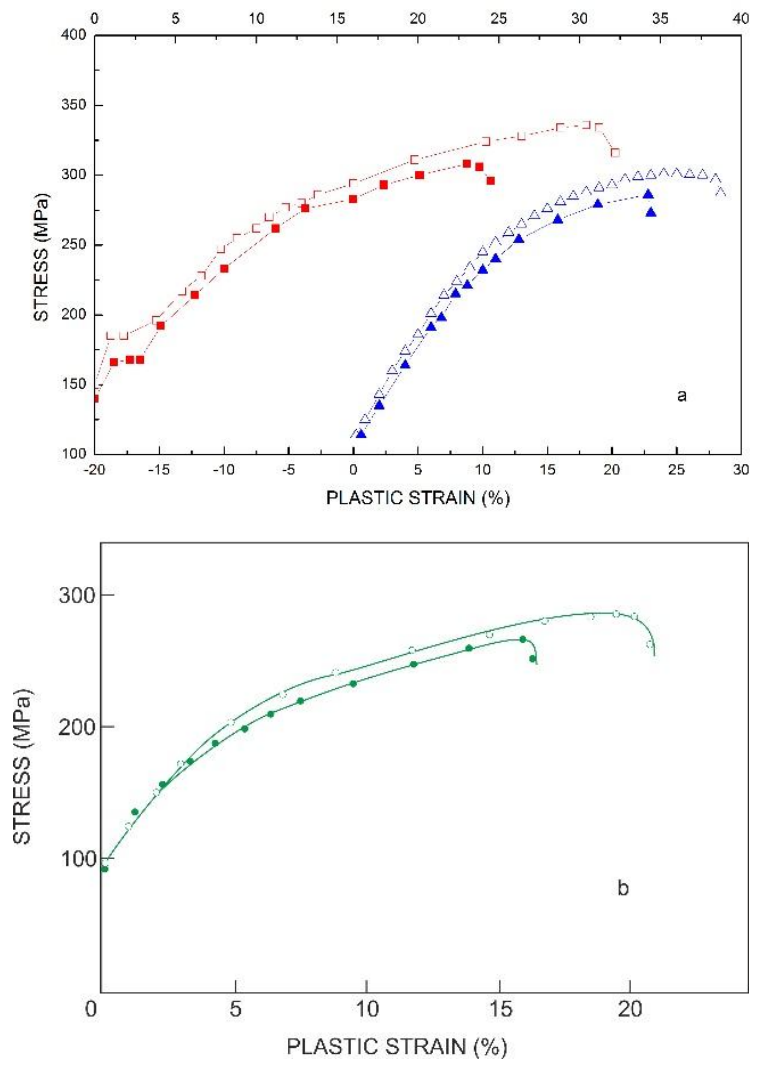

Fig. 4. (a) Deformation curves without (open symbols) and under (filled symbols) irradiation for Fe specimens $\left(\right.$ red $-T_{\text {ann }}=900^{\circ} \mathrm{C} ;$ blue $\left.-T_{\text {ann }}=1150^{\circ} \mathrm{C}\right)$. Electron energy $E=0.8 \mathrm{MeV}$, $\varphi=2.4 \times 10^{13} \mathrm{~cm}^{-2} \mathrm{~s}^{-1}$. (b) The same for steel $20 \mathrm{at}$ $E=0.5 \mathrm{MeV}, \varphi=2.4 \times 10^{13} \mathrm{~cm}^{-2} \mathrm{~s}^{-1}$ 


\section{CONCLUSIONS}

The present experiments were designed to allow comparison between sub-threshold and over-threshold electron irradiation of bcc and fcc metals, which did not show any significant difference.

The radiation-induced softening (RIS) effect was demonstrated for technically pure Fe as well as for previously studied $\mathrm{Al}$ and $\mathrm{Cu}$. It is represented by (i) reversible decrease of the yield stress by $\sim 1 \%$ at the moment of switching on electron beam and (ii) by irreversible decrease of the yield stress by $\sim 10 \%$ under continuous irradiation up to the material fracture.

The RIS effect on the elongation to fracture of Fe appears to be opposite to that for $\mathrm{Al}$ and $\mathrm{Cu}$, where electron irradiation increases elongation to fracture by $\sim 25 \ldots 30 \%$. In contrast to that, the elongation to fracture of Fe specimens was decreased by irradiation by $\sim 20 \%$, which is significant reduction as compared to the result obtained by the standard test. This discrepancy may have important implications regarding the programs forecasting the service lifetime of Fe-based structural steels.

We may conclude that the radiation-induced formation of DBs may change mechanical properties of materials under reactor conditions as compared to the surveillance specimens in out-reactor tests after equivalent irradiation dose. The RIS phenomenon needs further investigations due to its importance for the adequate qualification of the mechanical performance of the materials under reactor operating conditions.

\section{REFERENCES}

1. D. Terentyev, A. Dubinko, V. Dubinko, S. Dmitriev, E. Zhurkin. Interaction of discrete breathers with primary lattice defects in bcc Fe // Modelling Simul. Mater. Sci. 2015, Eng. 23, 085007-13.

2. R.T. Murzaev, A.A. Kistanov, V.I. Dubinko, D.A. Terentyev, S.V. Dmitriev, Moving discrete breathers in bcc metals V, Fe and W // Computational Materials Science. 2015, v. 98, p. 88-92.

3. V.I. Dubinko, A.N. Dovbnya, V.A. Kushnir, V.V. Mytrochenko, I.V. Khodak, V.P. Lebedev, V.S. Krylovskiy, S.V. Lebedev, V.F. Klepikov. Softening of metals in the course of electron irradiation // Proceedings of the XIX International Conference on Physics of Radiation Phenomena and Radiation Materials Science. Alushta, September 6-11, 2010.

4. V.I. Dubinko, A.N. Dovbnya, V.A. Kushnir, I.V. Khodak, V.P. Lebedev, V.S. Krylovskiy, S.V. Lebedev, V.F. Klepikov, P.N. Ostapchuk. Plasticization of face-centered metals under electron irradiation // Physics of the Solid State. 2012, v. 54, issue 12, p. 2442-2449.

5. O.A. Troitskii and V.I. Likhtman. On the combined effect of beta-radiation and a surface-active medium on the mechanical properties of zinc single crystals // Sov. Phys. Dokl. 1962, v. 4, v. 147, p. 874-877.

6. O.A. Troitsky, V.I. Spitsyn. Study of electronic interaction for plastic deformation of metal // Metallofizika. 1974, v. 51, p. 18-46.

7. A.V. Dubinko, S.V. Dmitriev. Influence of discrete breathers on the plasticity and strength of crystals // Letters on materials. 2013, v. 3, № 3, p. 239-247.

8. S. Flach, A.V. Gorbach. Discrete breathers // Phys. Rep. 2008, 467, p. 1-116.

9. M.E. Manley. Impact of intrinsic localized modes of atomic motion on materials properties // Acta Materialia. 2010, v. 58, p. 2926-2935.

Article received 04.10.2021

\section{РАДИАЦИОННО-ИНДУЦИРОВАННАЯ ПЛАСТИФИКАЦИЯ КРИСТАЛЛОВ \\ В.И. Дубинко, В.Н. Борисенко, В.А. Куинир, И.В. Ходак, В.В. Митроченко, В.О. Гамов}

При облучении кристаллов возникают атомные колебания кристаллической решетки, которые являются достаточно большими по амплитуде, так что линейного приближения и, следовательно, обычного фононного описания решетки недостаточно. В то же время, эти колебания локализованы и могут распространяться на большие расстояния $[1,2]$. В металлах и других кристаллах они называются дискретными бризерами (ДБ) и являются вторичными продуктами радиационного облучения, основными из которых являются точечные и протяженные дефекты, приводящие к радиационно-индуцированному упрочнению. Часть энергии трансформируется в ДБ, прежде чем распадаться на фононы. Таким образом, пока материал облучается в рабочих условиях как в реакторе, возникает значительное количество ДБ с энергиями порядка одного электронвольта, что помогает дислокациям открепляться от центров закрепления и приводит к радиационноиндуцированной пластификации (РИП) кристаллов, противостоящей радиационно-индуцированному упрочнению $[3,4]$. Этот эффект исследуется при (in-situ) импульсном и стационарном электронном облучении.

\section{РАДІАЦІЙНО-ІНДУКОВАНА ПЛАСТИФІКАЦІЯ КРИСТАЛІВ \\ В.І. Дубінко, В.М. Борисенко, В.А. Кушнір, І.В. Ходак, В.В. Мітроченко, В.О. Гамов}

При опроміненні кристалів виникають атомні коливання кристалічної решітки, які є достатньо великими за амплітудою, так що лінійного наближення i, отже, звичайного фононного опису решітки недостатньо. У той же час, ці вібрації локалізовані і можуть проїжджати великі відстані $[1,2]$. У металах та інших кристалах вони називаються дискретними бризерами (ДБ) і $€$ вторинними продуктами пошкодження опроміненням, основними з яких є точкові та розширені дефекти, що призводять до радіаційно-індукованого зміцнення. Частина енергії, що залишилася, трансформується в ДБ, перш ніж розпадатися на фонони. Таким чином, поки матеріал опромінюється в робочих умовах, як у реакторі, існує значна кількість ДБ з енергіями порядку одного електронвольта, що допомагає дислокаціям відкріпитися від центрів закріплення, приводячи до радіаційно-індукованої пластифікації (РІП) кристалів, що протистоїть радіаційно-індукованому зміцненню $[3,4]$. Цей ефект досліджується при (in-situ) імпульсному та стаціонарному електронному опроміненні. 